Scientia Agricola

http://dx.doi.org/10.1590/0103-9016-2014-0094

\title{
Use of organic compost produced from slaughterhouse waste as fertilizer in soybean and corn crops
}

Walder Antonio Gomes de Albuquerque Nunes ${ }^{1 *}$, June Faria Scherrer Menezes², Vinícius de Melo Benites ${ }^{3}$, Sérgio Araújo de Lima Junior ${ }^{4}$, Anderson dos Santos Oliveira ${ }^{5}$

'Embrapa Western Region Agriculture, Rod. BR 163, km 253.6, C.P. 449 - 79804-970 - Dourados, MS - Brazil. 2Rio Verde University/Agronomy College, C.P. 104 - 75901970 - Rio Verde, GO - Brazil.

${ }^{3}$ Embrapa Soils, R. Jardim Botânico, 1024 - 22460-000 Rio de Janeiro, RJ - Brazil.

${ }^{4}$ Adecoagro/lvinhema Valley - Dept. of Fertirrigation - R. Continental, km 15, Takuarê Farm - 79785-000 - Angélica, MS - Brazil.

${ }^{5}$ CAMDA, Av. Marcelino Pires, 5285 - 79840-630 -

Dourados, MS - Brazil.

*Corresponding author <walder.nunes@embrapa.br>

Edited by: Leônidas Carrijo Azevedo Mel

Received June 02, 2014

Accepted December 04, 2014
ABSTRACT: Slaughterhouses generate large amounts of rumen content and its use as a fertilizer may offer an environmentally friendly strategy for its management. The effect of an organic fertilizer produced from slaughterhouse waste on the fertility of sandy and clayey soils as well as soybean yield (Glycine max L.) and corn (Zea mays L.) crops was evaluated. Field experiments were set up and five rates up to $16 \mathrm{t} \mathrm{ha}^{-1}$ of organic fertilizer (293 kg ha-1 $\mathrm{N}, 334 \mathrm{~kg} \mathrm{ha}^{-1} \mathrm{P}$ and $27 \mathrm{~kg} \mathrm{ha}^{-1} \mathrm{~K}$ ) were applied annually, before sowing in spring/summer, as well as a mineral fertilization of $300 \mathrm{~kg} \mathrm{ha}^{-1}$ in the formulation 2-20-20 for soybean and $300 \mathrm{~kg} \mathrm{ha}^{-1}$ of 12-15-15 for corn. The organic fertilizer changed soil fertility in the field experiments by increasing $\mathrm{pH}, \mathrm{Ca}$, Mg, K, P-Mehlich and P-resin. Such effects were more evident in the sandy than in the clayey soil, and the most superficial layer was affected more. The organic fertilizer rate needed to achieve maximum yield decreased for corn in both soils and for soybean in the sandy soil, although the amounts required may still be regarded as high.

Keywords: organic fertilization, nutrient recycling

\section{Introduction}

Livestock production has rapidly expanded in Brazil over the last decade (IBGE, 2013). In 2012 it generated more than 900,000 tons of bovine rumen content, which is the main waste produced by this activity. This waste must be properly disposed of if environmental damage is to be avoided, and the most usual way to do this is by burying it in landfills, which represents an additional cost to the beef production chain and constitutes a waste of resources. Its recycling as fertilizers for growing crops may be an environmentally friendly strategy for managing the large amounts of waste produced.

These waste products have been used as raw material for manufacturing organic composts used to fertilize crops, but few products can be found in the market. However, agricultural performance assessments are very rare and generally focus on vegetable and forage crops (Roy et al., 2013).

Studies evaluating the response of grain crops, such as soybean (Glycine max L.) and corn (Zea mays L.), to organic fertilizers usually focus on poultry manure, fresh or composted, (Adeli et al., 2005; Slaton et al., 2013), biosolid waste (sewage sludge) (Lixandru et al., 2011), or pig slurry (Barbazan et al., 2009). Adeli et al. (2005) observed that soybean grain yield, nitrogen $(\mathrm{N})$ and phosphorus $(\mathrm{P})$ uptake increased quadratically in line with increases broiler litter and commercial fertilizer application rates, and broiler litter treatment produced a grain yield of $3 \%$ than commercial fertil- izer. Poultry litter was a valid alternative to mineral fertilizer for soybean growth and yield (Slaton et al., 2013).

Higher corn production was obtained using biosolid fertilization with $50 \mathrm{tha}^{-1}$, which provided a production gain $20 \%$ higher than the unfertilized treatment and $5 \%$ higher than the mineral supply (Lixandru et al., 2011). Yield corn increases were observed by Barbazan et al. (2009) in response to manure and mineral fertilizer, mainly when both were applied together. As regards the soil attributes, Adeli et al. (2005) observed an increase in $\mathrm{pH}$ and $\mathrm{P}$ levels when poultry manure was applied, while Slaton et al. (2013) found out that this waste was as effective as mineral fertilizers in supplying $\mathrm{P}$ and $\mathrm{K}$ to the soybean crop.

In this study, we aimed to evaluate the agronomic performance of an organic compost produced from slaughterhouse waste, in successive soybean and off-season corn crops, as well as its effects on soil fertility.

\section{Materials and Methods}

The compost used in the experiments was a commercial product made from the waste of slaughtered cattle (with great emphasis on rumen content), with the addition of tannery sludge, waxing and trimming waste, vegetable waste, coal boilers, sawdust, basalt powder, phosphorite and talc. The mixture of materials was homogenized and thereto an aqueous solution was added containing compost accelerator microorganisms such as 
bacteria and fungi. The product was stored in conical cells, maintained with forced aeration for ten days until the compound was ready for use.

For the analysis of total mineral content in the samples of the organic compost, nitric perchloric acid digestion was used, consisting of the digestion of 500 $\mathrm{mg}$ of a sample with $8 \mathrm{~mL}$ of $65 \% \mathrm{HNO}_{3}$, placed on a hot plate to gradually raise the temperature to $180{ }^{\circ} \mathrm{C}$ and maintained at this temperature until the volume was reduced to about 1.0 to $2.0 \mathrm{~mL}$. After $5 \mathrm{~mL}$ of $72 \%$ $\mathrm{HClO}_{4}$ were added the sample was maintained at 200 ${ }^{\circ} \mathrm{C}$ until the volume was reduced by half, and then it was filtered and the volume completed to $50.0 \mathrm{~mL}$. The extract was used for subsequent determination using the atomic absorption spectrometric method $(\mathrm{Ca}, \mathrm{Mg}, \mathrm{Cu}$, $\mathrm{Zn})$, molecular absorption $(\mathrm{P})$, emission photometry $(\mathrm{K}$, $\mathrm{Na}$ ) and turbidimetry (S). For nitrogen, sulfuric digestion with catalyst salts in a digesting block was employed, with semi-micro Kjeldahl distillation (Miyazawa et al., 1999).

The experiments were conducted using two soils from the state of Matto Grosso do Sul, Brazil, with contrasting textures: (i) a sandy dystrophic Rhodic Hapludox from Batayporã, $\left(22^{\circ} 14^{\prime} 06.77^{\prime \prime}\right.$ S; 5316'30.53" W), dubbed as "sandy soil", and (ii) a clayey dystroferric Rhodic Hapludox from Dourados $\left(22^{\circ} 16^{\prime} 42.4524^{\prime \prime}\right.$ S; $54^{\circ} 48^{\prime} 49.9134^{\prime \prime}$ W), dubbed as "clayey soil".

The first sowing took place in Oct 2008, with soybean, in cultivar BRS 239. After the harvest of soybeans, corn cultivar BRS 2020 was sown in Feb 2009, both under a no tillage system. The same procedure was adopted in seasons 2009/10 and 2010/11.

Organic fertilizer was applied annually before the spring/summer sowing. The treatments were: T0 - control without fertilization; $\mathrm{T} 1-4 \mathrm{tha}^{-1}$ of organic compost; T2 - $8 \mathrm{t} \mathrm{ha}^{-1}$ of organic compost; T3 - $12 \mathrm{t} \mathrm{ha}^{-1}$ of organic compost; $\mathrm{T} 4-16 \mathrm{t} \mathrm{ha}^{-1}$ of organic compost, always with fresh amounts (15\% moisture); and T5 fertilization with mineral fertilizers (NPK) at the rates usually applied to crops in the region $\left(300 \mathrm{~kg} \mathrm{ha}^{-1}\right.$ of the formulation 2-20-20 for soybean and $300 \mathrm{~kg} \mathrm{ha}^{-1}$ of 12-15-15 for corn). The $16 \mathrm{t} \mathrm{ha}^{-1}$ rate of organic compost provides $293 \mathrm{~kg} \mathrm{ha}^{-1} \mathrm{~N}, 334 \mathrm{~kg} \mathrm{ha}^{-1} \mathrm{P}$ and $27 \mathrm{~kg} \mathrm{ha}^{-1}$ $\mathrm{K}$, which exceeds the joint requirement of $\mathrm{N}$ and $\mathrm{P}$ in soybean and corn crops, but is insufficient to meet the requirement of K. Soybean was planted at a spacing of $0.45 \mathrm{~m}$ between rows and 16 plants per meter, while for corn the spacing was $0.9 \mathrm{~m}$ between rows and 5 plants per meter. Four replications per treatment were used, in a randomized block arrangement. The plots were $5.4 \times$ $6.0 \mathrm{~m}$, and the effective cultivation area consisted of two internal rows, $3 \mathrm{~m}$ long. At the end of the corn crop in the third year, in Aug 2011, soil samples were taken for chemical analyses.

The chemical analyses on the soil samples were performed according to Claessen (1997): $\mathrm{pH}$ was measured with a glass electrode $\mathrm{pH}$ meter at a 1:2.5 soil/distilled water ratio after 5 min shaking and left to stand for
30 min; exchangeable $\mathrm{Ca}^{2+}$ and $\mathrm{Mg}^{2+}$ were extracted with $1 \mathrm{M} \mathrm{KCl}$ at 1:10 soil-to-solution ratio and determined by atomic absorption spectrophotometry (AAS); available $\mathrm{P}$ and $\mathrm{K}$ were extracted with Mehlich-1 solution 10.0125 $\mathrm{M} \mathrm{H}_{2} \mathrm{SO}_{4}+0.05 \mathrm{M} \mathrm{HCl}$ ) with a soil-to-solution ratio of 1:10 determined by flame emission spectrophotometry. During the extraction ( $\mathrm{KCl}$ or Mehlich-1), solutions were stirred at $220 \mathrm{rpm}$ in an Erlenmeyer flask for $5 \mathrm{~min}$ and left to stand for $16 \mathrm{~h}$. Then, an aliquot of supernatant was taken for analysis.

Soil $\mathrm{P}$ was also extracted with an anion-exchange resin. The resin had been previously saturated with $1 \mathrm{M}$ $\mathrm{NaHCO}_{3} \mathrm{pH} 8.5$ and then mixed with in a $1: 1: 10$ soil-resin-distilled water ratio, shaken for $16 \mathrm{~h}$ at $220 \mathrm{rpm}$ and then left to stand for 16 hours. Soil $\mathrm{P}$ was extracted from the resin with $50 \mathrm{~mL}$ mixture of $0.8 \mathrm{M} \mathrm{NH}_{4} \mathrm{Cl}+0.2 \mathrm{M}$ $\mathrm{HCl}$ (Raij et al., 2001). Both P-Mehlich and P-resin were determined by molecular absorption spectrometry in the presence of ascorbic acid. Organic carbon analyses were performed using a Total Organic Carbon Analyser (TOC$\mathrm{V}$ cpm Shimadzu), with a sample of $200 \mathrm{mg}$ oxidized at $900{ }^{\circ} \mathrm{C}$.

Soil analysis data and soybean and maize yield were subjected to variance analysis and, where significant effects were detected $(p<0.05)$, regression equations were adjusted for the variables assessed and the compost rates applied.

\section{Results and Discussion}

Soils differed in texture and fertility, and the clayey soil was richer than the sandy soil in both the layers analyzed (Table 1). The presence of sludge liming (tannery waste) mixed with ruminal content from the slaughterhouse provided high levels of $\mathrm{Ca}^{2+}(8.79 \%)$ and $\mathrm{Na}^{+}$ $(0.30 \%)$ to the fresh compost ( $15 \%$ moisture) and a high $\mathrm{pH}$ (8.0). This high $\mathrm{pH}$ value, combined with a low C:N ratio (6.2), provides conditions conducive to ammonia volatilization. Nitrogen (1.83\%) and phosphorus (2.09\%) levels are compatible with other organic composts or solid wastes (Adeli et al., 2005; Slaton et al., 2013; Lixandru et al., 2011). The compost presented $18.22 \%$ of organic carbon, $\mathrm{K}$ at $0.17 \%$ and $\mathrm{S}$ at $0.94 \%$.

Because the compost was alkaline, its application increased the $\mathrm{pH}$ of both soils (Figure 1), corroborating what has been observed as a liming effect, as reported by Oliveira and Pavan (1996). There were small differences $(p<0.05)$ between the $0-10 \mathrm{~cm}$ and $10-20 \mathrm{~cm}$ layers. These results are in agreement with the findings of Bulluck III et al. (2002), who evaluated a composted cotton (Gossypium hirsutum L.) gin trash, composted yard waste and cattle manure.

The effect of the compost on soil $\mathrm{pH}$ can also be due to the transferring of $\mathrm{H}^{+}$ions from the soil to the organic matter (Wong et al., 1998) or to increasing the aluminum complexation by organic molecules (Hoyt and Turner, 1975). It is possible that these three mechanisms were active simultaneously. The sandy soil had a greater 
Table 1 - Original values of pH, soil organic matter (SOM), P, K, Ca, Mg, Na, Cu, Fe, Mn, Zn, sand, silt and clay at the 0-10 cm layers and at a depth of $10-20 \mathrm{~cm}$ of soils used in field trials with soybean and corn.

\begin{tabular}{|c|c|c|c|c|c|c|c|c|c|c|c|c|c|c|}
\hline & $\mathrm{pH}$ & SOM & $P$ & K & $\mathrm{Ca}$ & $\mathrm{Mg}$ & $\mathrm{Na}$ & $\mathrm{Cu}$ & $\mathrm{Fe}$ & $\mathrm{Mn}$ & $\mathrm{Zn}$ & Sand & Silt & Clay \\
\hline & & $\mathrm{g} \mathrm{kg}^{-1}$ & $\mathrm{mg} \mathrm{dm^{-3 }}$ & 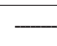 & $-m$ & ${ }_{c} \mathrm{dm}^{-3}$ & $\bar{Z}$ & 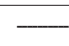 & $-n$ & $m^{-3}-$ & - & 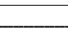 & $\mathrm{g} \mathrm{kg}^{-1}$ & \\
\hline $0-10 \mathrm{~cm}$ & 4.8 & 19 & 1.0 & 1.6 & 12.1 & 4.3 & 0.3 & 0.6 & 9.3 & 4.4 & 0.1 & 832 & 29 & 139 \\
\hline $10-20 \mathrm{~cm}$ & 4.1 & 9 & 0.2 & 0.3 & 3.1 & 0.8 & 0.3 & 0.6 & 7.2 & 3.7 & 0.1 & 798 & 25 & 177 \\
\hline $0-10 \mathrm{~cm}$ & 6.2 & 28 & 2.8 & 3.6 & 48.1 & 23.8 & 0.9 & 13.4 & 21.7 & 97.5 & 0.6 & 86 & 141 & 773 \\
\hline $10-20 \mathrm{~cm}$ & 5.7 & 12 & 1.5 & 2.3 & 41.1 & 21.2 & 0.8 & 12.4 & 18.8 & 77.5 & 0.5 & 49 & 124 & 827 \\
\hline
\end{tabular}
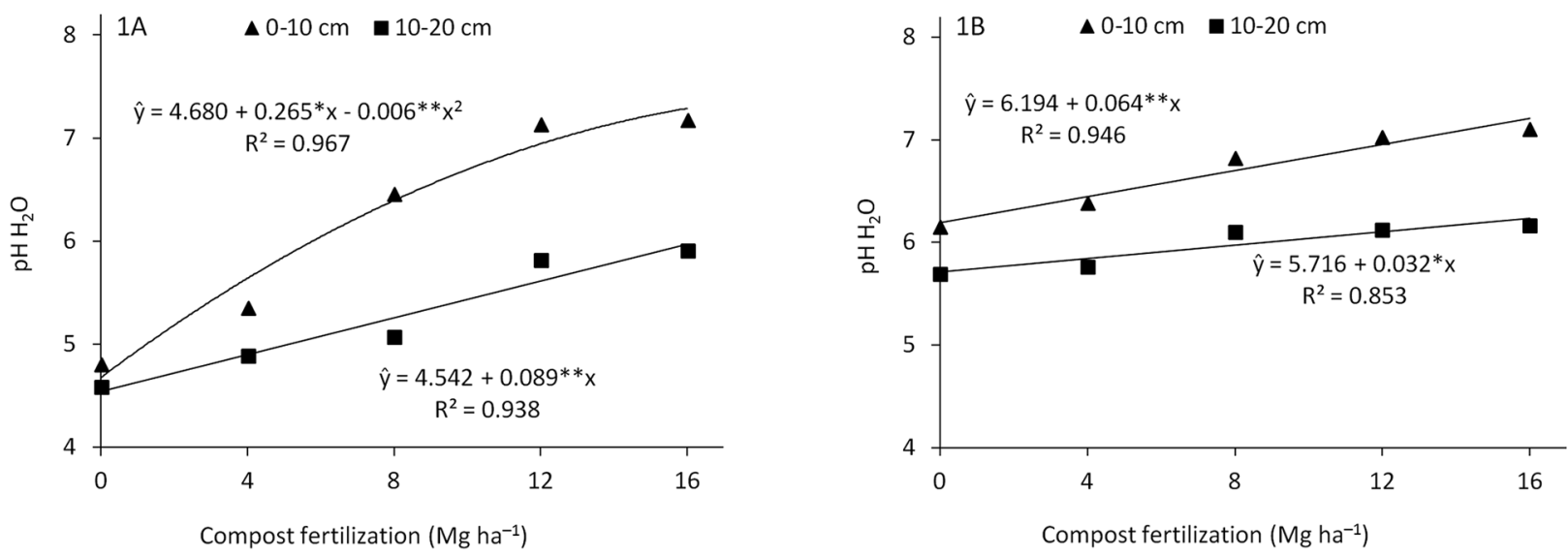

Figure $1-\mathrm{pH}-\mathrm{H}_{2} \mathrm{O}$ in sandy (A) and clayey soil (B) in the layers 0-10 cm layers and at a depth of $10-20 \mathrm{~cm}$ in successive soybean and off-season corn crops fertilized with organic compost produced from slaughterhouse waste over three years.

$\mathrm{pH}$ range, and a quadratic model was set as a response to the rates applied, when compared to the clayey soil, whose response was linear (Figure 1). As these soils have a similar kaolinitic mineralogy, the lower clay and organic matter content in the sandy soil could explain its lower buffering capacity and, as a consequence, the lower resistance to changes in soil $\mathrm{pH}$.

There was a small difference in the increase in $\mathrm{Ca}^{2+}$ content as a response to rates of compost between soils, and the differences observed are explained by the different initial levels of this cation (Figure $2 \mathrm{~A}-\mathrm{B}$ ). The $\mathrm{Ca}^{2+}$ content had a strong increase in the most superficial layer, while the increase was lower in the 10-20 cm layer (Figure $2 \mathrm{~A}-\mathrm{B}$ ), perhaps because of the low mobility of this cation in the soil (Friesen et al., 1982). However, in the presence of organic waste, $\mathrm{Ca}^{2+}$ mobility can increase due to the formation of organic and metallic complexes, which could explain increased values of this cation also in the subsurface (Friesen et al., 1982).

The $\mathrm{Mg}^{2+}$ content in both soils followed the same trend observed for $\mathrm{Ca}^{2+}$ as a response to the compost rates applied; although the absolute values were lower (Figure 2 C-D). A small increase was observed in $\mathrm{Mg}^{2+}$ content in this soil, at both depths. Responses of $\mathrm{Mg}^{2+}$ content in the clayey soil were greater than in the sandy soil, reflecting the higher retention capacity of the former.
The $\mathrm{K}^{+}$content in the soil also increased linearly with the rates applied, with a difference between these soils, depending on the initial $\mathrm{K}^{+}$levels (Figure $2 \mathrm{E}-\mathrm{F}$ ). Wong et al. (1999) observed the same effect of the compost made from cattle manure on the $\mathrm{K}^{+}$content in soil. Regarded as an element with high mobility in soil, higher rates of the compost could cause a more significant increase in the levels of this cation in the layer 10-20 cm deep, especially in the sandy soil, which was not observed in this work.

The slopes of the linear equations for the sandy soil for $\mathrm{K}^{+}$and $\mathrm{Mg}^{2+}$ (cations regarded as mobile in soil) were lower than those observed in the clayey soil, indicating greater probability of leaching. Franchini et al. (2003) observed a significant leaching of $\mathrm{K}^{+}$and $\mathrm{Mg}^{2+}$ when the soil was fertilized with poultry manure, and the cations were percolated below $50 \mathrm{~cm}$ deep.

There was a linear effect of the rates of the compost in the availability of $\mathrm{P}$ extracted with Mehlich-1. This is consistent with Eghball and Power (1999), who observed increases in P levels after four years of compost and manure amendment. The $\mathrm{P}$ levels in the layer $0-10 \mathrm{~cm}$ deep showed a marked increase with the application of the organic compost (Figure $3 \mathrm{~A}-\mathrm{B}$ ), as a consequence of the supplying of this element by the compost. In the underlying layer, $\mathrm{P}$ levels increased, although to a lesser magnitude, as 

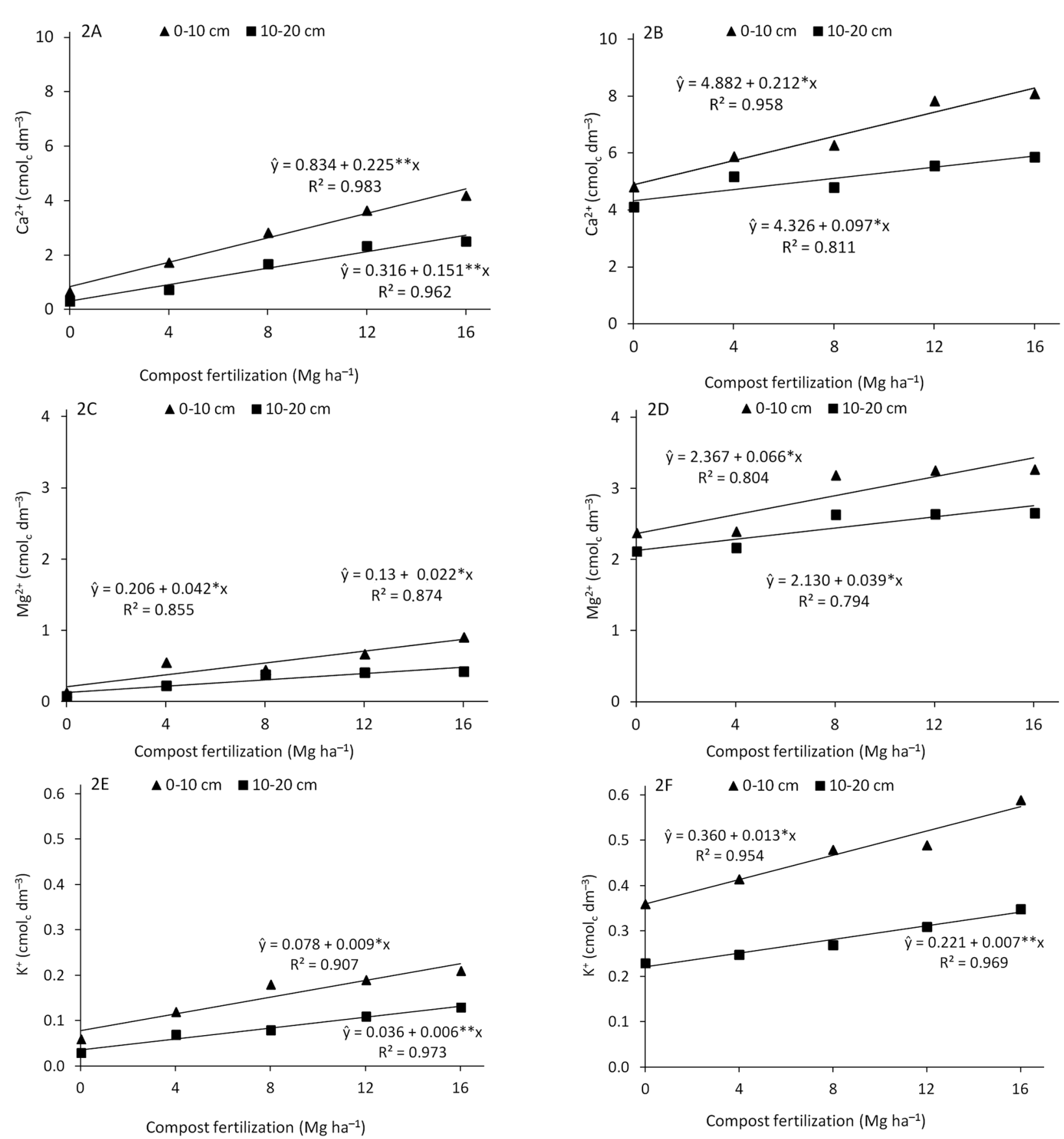

Figure 2 - Levels of $\mathrm{Ca}^{2+}, \mathrm{Mg}^{2+}$ and $\mathrm{K}^{+}$in sandy (A; C; E) and clay soil (B; D; F) in the 0-10 cm layers and and at a depth of 10-20 $\mathrm{cm}$ in response to successive soybean and off-season corn crops fertilized with organic compost produced from slaughterhouse waste over three years.

a reflection of the low mobility of this element in soil (Dias et al., 2000; Villani et al., 1998).

It is possible that the $\mathrm{P}$ added as phosphorite is not immediately solubilized due to the $\mathrm{pH}$ values of the compost along with relatively high calcium contents. It is also possible that precipitation of the calcium phosphate took place, which would decrease the $\mathrm{P}$ level already present in the soil (Haynes, 1982). In fact, a difference between the $\mathrm{P}$ levels obtained by the different extractors was identified in the 0-10 cm layer. The P-Mehlich increased linearly as a function of the increased compost rates (Figure $3 \mathrm{~A}-\mathrm{B}$ ), while the P-resin had a quadratic behavior (Figure $3 \mathrm{C}-\mathrm{D}$ ), indicating that, at higher compost rates, part of the $\mathrm{P}$ would not be available to plants, and would remain in the form of calcium phosphate. The Ca-phosphate complexes were likely inconveniently solubilized by the acid extractor Mehlich-1, inducing an overestimation of the content of 
this element, thereby corroborating the observation of Gatiboni et al. (2003). Sharpley et al. (2004) found similar results when studying soils amended with manure, which overestimate $\mathrm{P}$ soil content as extracted with Mehlich 3. Otherwise, Nziguheba et al. (1998) increased the available soil $\mathrm{P}$ after application of aged cattle
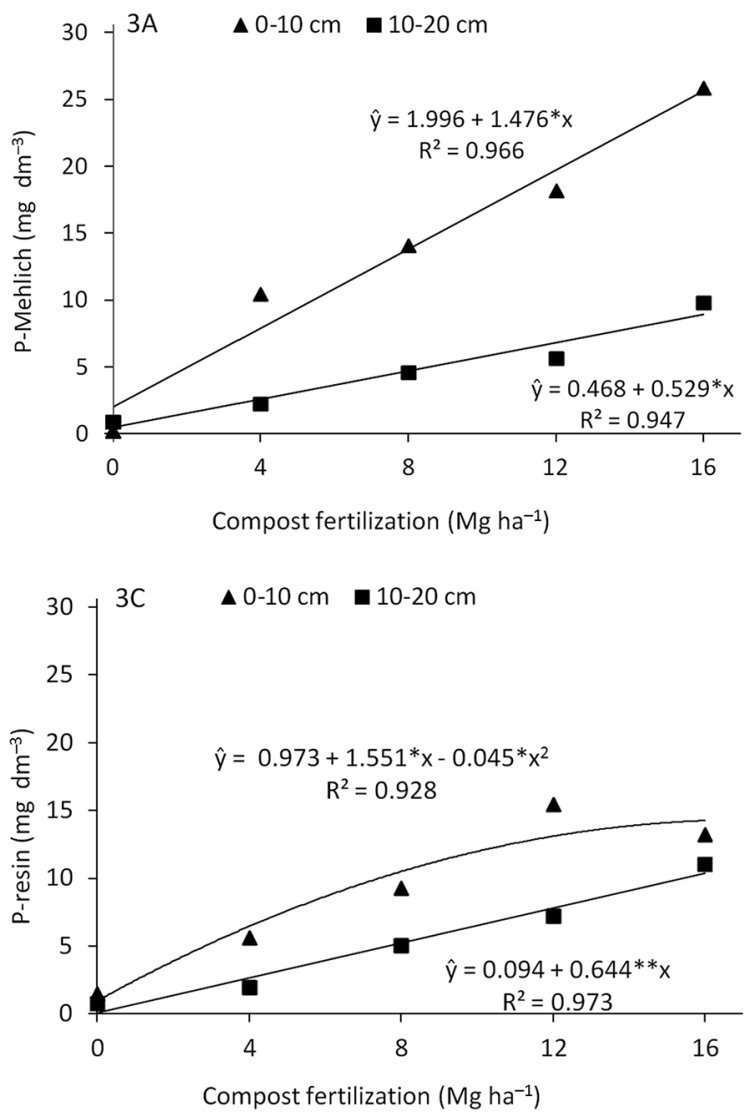

manure, which provided this nutrient and decreased $\mathrm{P}$ adsorption sites, blocked by organic matter released by manure decomposition.

A small variation was found in the soil organic matter (SOM) content in the topsoil $(0-10 \mathrm{~cm})$ (Figure 4 A-B), while in the $10-20 \mathrm{~cm}$ layer there was no change.
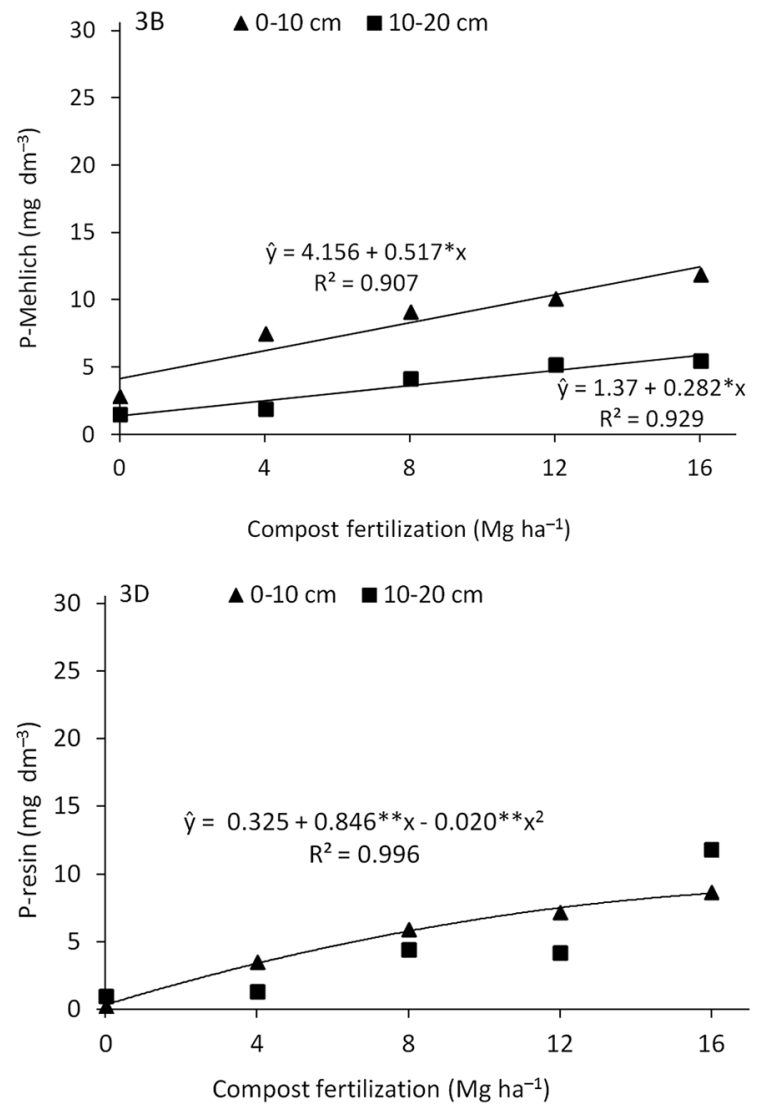

Figure 3 - Levels of P-Mehlich in sandy (A) and clay soil (B) and P-resin in sandy (C) and clay soil (D) in the 0-10 cm layers and and and at a depth of $10-20 \mathrm{~cm}$ in response to successive soybean and off-season corn crops fertilized with organic compost produced from slaughterhouse waste over three years.
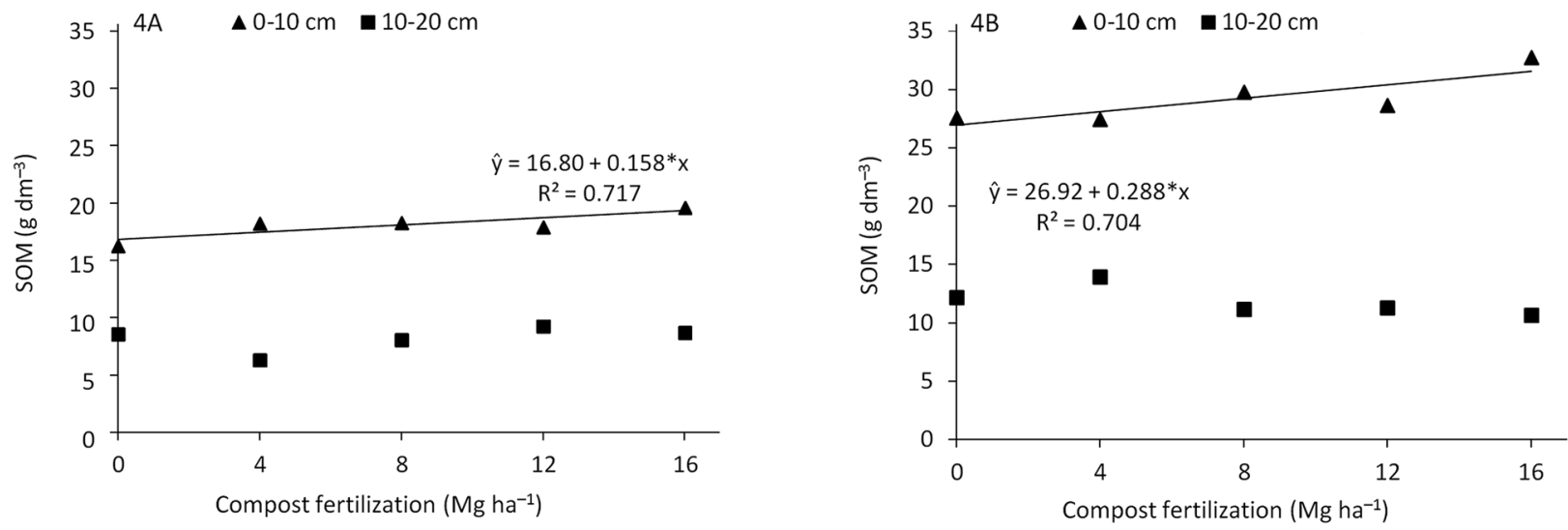

Figure 4 - Levels of soil organic matter (SOM) in sandy (A) and clay soil (B) in the 0-10 cm layers and at a depth of 10-20 cm in response of successive soybean and off-season corn crops fertilized with organic compost produced from slaughterhouse waste over three years. 
The same was observed by Maillard and Angers (2014). Slight increases in SOM (Kapkiyai et al., 1999) or even decreased carbon levels due to a priming effect or secondary mineralization (Fontaine et al., 2004) were observed after applying organic composts.

The application of the organic compost produced from slaughterhouse waste has provided quadratic responses in the yield of soybean and corn crops (Figure $5 \mathrm{~A}-\mathrm{C}$ and Figure $5 \mathrm{D}-\mathrm{F}$ ), although great variation in the yields of these crops was observed over the years, probably due to the climatic conditions; there was even a reversal in the prospect towards improved yield in Dourados (clayey soil), in the corn crop for the season 2010/11, when the culture experienced low rainfall and frosts.

The rates required to achieve the maximum yields were above the dose range in the early applications of compost conducted in both soils and both crops, except for corn in the clayey soil (Table 2). However,
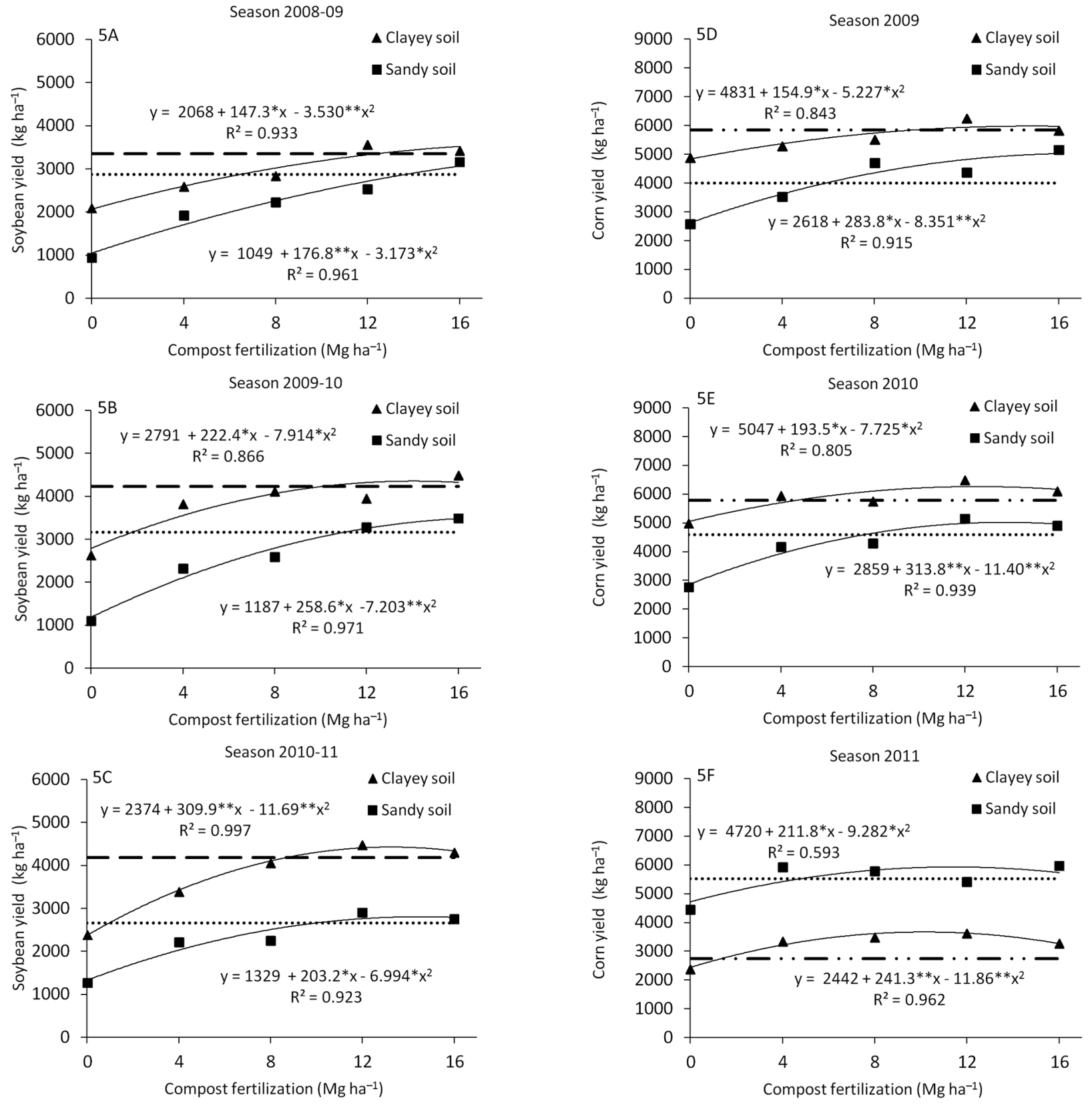

Figure 5 - Soybean yield in response to the organic compost fertilization in the crops harvested in 2009 (A), 2010 (B), 2011 (C) and corn yield in response to the organic compost fertilization in the crops harvested in 2009 (D), 2010 (E) and 2011 (F). The dashed line indicates the yield achieved with mineral fertilization (300 $\mathrm{kg} \mathrm{ha}^{-1}$ de 2-20-20) in the clayey soil and the dotted line indicates the yield achieved the same way in sandy soil. 
Table 2 - Doses of organic compost required to achieve maximum yield in trials with soybean and corn, harvested from 2009 to 2011.

\begin{tabular}{lccc}
\hline & 2009 & 2010 & 2011 \\
\cline { 2 - 4 } Soybean & \multicolumn{3}{c}{ S of compost ha soil ${ }^{-1}$} \\
Corn & 27.9 & 17.9 & 14.5 \\
\hline \multirow{3}{*}{ Soybean } & 17.0 & 13.8 & 11.4 \\
Corn & 20.8 & Clayey soil \\
\hline
\end{tabular}

we can hypothesize the existence of a cumulative effect in applications of the organic compost with the decrease in these rates observed during the course of the experiment. This effect was clear in the corn crop in both soils and in the soybean crop in the clayey soil, although the amounts required after three years of application may still be regarded as high, about $10-11 \mathrm{t} \mathrm{ha}^{-1}$. Such amounts hinder the logistics required for applying the compost, and results in a greater expenditure of time. The decreased rate to achieve maximum yield, as well as to match the yield achieved by mineral fertilizers, agrees with the claims of Miller and Mackenzie (1978), who evaluated other types of organic wastes and found that their continued application led to higher yields than those obtained with mineral fertilization.

\section{References}

Adeli, A.; Sistani, K.R.; Rowe, D.E.; Tewolde, H. 2005. Effects of broiler litter on soybean production and soil nitrogen and phosphorus concentrations. Agronomy Journal 97: 314-321.

Barbazan, M.M.; Mallarino, A.P.; Sawyer, J.E. 2009. Liquid swine manure phosphorus utilization for corn and soybean production. Soil Science Society of America Journal 73: 654662.

Bulluck III, L.R.; Brosius, M.; Evanylo, G.K.; Ristaino, J.B. 2002. Organic and synthetic fertility amendments influence soil microbial, physical and chemical properties on organic and conventional farms. Applied Soil Ecology 19: 147-160.

Claessen, M.E.C. 1997. Methods of Soil Analysis Manual = Manual de Métodos de Análise de Solo. 2ed. Embrapa-CNPS, Rio de Janeiro, RJ. Brazil. (in Portuguese).

Dias, L.E.; Fernandez, J.Q.; Barros, N.F.; Novais, R.F.; Moraes, É.J.; Daniels, W. L. 2000. Availability of phosphorus in a Brazilian Oxisol cultivated with eucalyptus after nine years as influenced by phosphorus-fertilizer source, rate, and placement. Communications in Soil Science and Plant Analysis 31: 837-847.

Eghball, B.; Power, J.F. 1999. Phosphorus-and nitrogen-based manure and compost applications corn production and soil phosphorus. Soil Science Society of America Journal 63: 895901.

Fontaine, S.; Bardoux, G.; Abbadie, L.; Mariotti, A. 2004. Carbon input to soil may decrease soil carbon content. Ecology Letters 7: $314-320$.
Franchini, J.C.; Hoffmann-Campo, C.B.; Torres, E.; Miyazawa, M.; Pavan, M.A. 2003. Organic composition of green manure during growth and its effect on cation mobilization in an acid Oxisol. Communications in Soil Science and Plant Analysis, 34: 2045-2058.

Friesen, D.K.; Juo, A.S.R.; Miller, M.H. 1982. Residual value of lime and leaching of calcium in a kaolinitic Ultisol in the high rainfall tropics. Soil Science Society of America Journal 46: 1184-1189.

Gatiboni, L.C.; Kaminski, J.; Rheinheimer, D.S.; Brunetto, G. 2003. Superphosphate and rock phosphates as phosphorus sources for grass-clover pasture on a limed acid soil in southern Brazil. Communications in Soil Science and Plant Analysis 34: 2503-2514.

Haynes, R.J. 1982. Effects of liming on phosphate availability in acid soils. Plant and Soil 68: 289-308.

Hoyt, P.B.; Turner, R.C. 1975. Effects of organic materials added to very acid soil on $\mathrm{pH}$, aluminium, exchangeable $\mathrm{NH} 4$ and crop yields. Soil Science 119: 227-237.

Instituto Brasileiro de Geografia e Estatística [IBGE]. 2013. SIDRA - Automatic Recovery System = Sistema IBGE de Recuperação Automática. Rio de Janeiro, RJ, Brazil. Available at: http://www.sidra.ibge.gov.br/ [Accessed May 23, 2013] (in Portuguese).

Kapkiyai, J.J.; Karanja, N.K.; Qureshi, J.N.; Smithson, P.C.; Woomer, P.L. 1999. Soil organic matter and nutrient dynamics in a Kenyan nitisol under long-term fertilizer and organic input management. Soil Biology and Biochemistry 31: 17731782 .

Lixandru, B.; Dragomir, N.; Pătroescu, V.; Morariu, F.; Pricop, A.; Popescu, D. 2011. Testing the remanent fertilizing effect that the compost prepared with slurry resulted from urban treatment plants has on corn crops. Scientific Papers Animal Science and Biotechnologies 44: 486-488.

Maillard, É.; Angers, D.A. 2014. Animal manure application and soil organic carbon stocks: a meta-analysis. Global Change Biology 20: 666-679.

Miller, P.L.; Mackenzie, A.F. 1978. Effects of manures, ammonium nitrate and S-coated urea on yield and uptake of $\mathrm{N}$ by corn and on subsequent inorganic $\mathrm{N}$ levels in soils in southern Quebec. Canadian Journal of Soil Science 58: 153-158.

Miyazawa, M.; Pavan, M.A.; Muraoka, T.; Carmo, C.A.F.S.; Mello, W.J. 1999. Chemical analysis of plant tissue. p. 172223. In: Silva, F.C., org. Manual of chemical analysis of soils, plants and fertilizers = Manual de análises químicas de solos, plantas e fertilizantes. Embrapa, Brasília, DF, Brazil (in Portuguese).

Nziguheba, G.; Palm, C.A.; Buresh, R.J.; Smithson, P.C. 1998. Soil phosphorus fractions and adsorption as affected by organic and inorganic sources. Plant and Soil 198: 159-168.

Oliveira, E.L.; Pavan, M.A. 1996. Control of soil acidity in notillage system for soybean production. Soil and Tillage Research 38: 47-57.

Raij, B. van; Andrade, J.C.; Cantarella, H.; Quaggio, J.A. 2001. Chemical Analysis to Evaluate the Fertility of Tropical Soils = Análise Química para Avaliação da Fertilidade de Solos Tropicais. Instituto Agronômico, Campinas, SP, Brazil. (in Portuguese). 
Roy, M.; Karmakar, S.; Debsarcar, A.; Sen, P.K.; Mukherjee, J. 2013. Application of rural slaughterhouse waste as an organic fertilizer for pot cultivation of solanaceous vegetables in India. International Journal of Recycling of Organic Waste in Agriculture 2: 6 .

Sharpley, A.N.; McDowell, R.W.; Kleinman, P.J.A. 2004. Amounts, forms, and solubility of phosphorus in soils receiving manure. Soil Science Society of America Journal 68: 2048-2057.

Slaton, N.A.; Roberts, T.L.; Golden, B.R.; Ross, W.J.; Norman, R.J. 2013. Soybean response to phosphorus and potassium supplied as inorganic fertilizer or poultry litter. Agronomy Journal 105: 812-820.
Villani, E.M.A.; Barros, N.F.; Novais, R.F.; Costa, L.M.; Neves, J.C.L.; Alvarez, V.; Comerford, N.B. 1998. Phosphorus diffusive flux as affected by phosphate source and incubation time. Soil Science Society of America Journal 62: 1057-1061.

Wong, J.W.C.; Ma, K.K.; Fang, K.M.; Cheung, C. 1999. Utilization of a manure compost for organic farming in Hong Kong. Bioresource Technology 67: 43-46.

Wong, M.T.F.; Nortcliff, S.; Swift, R.S. 1998. Method for determining the acid ameliorating capacity of plant residue compost, urban waste compost, farmyard manure, and peat applied to tropical soils. Communications in Soil Science and Plant Analysis 29: 2927-2937. 